\title{
BMJ Open Determinants of regular smoking onset in South Africa using duration analysis
}

\author{
Nicole Vellios, Corné van Walbeek
}

To cite: Vellios N, van Walbeek C. Determinants of regular smoking onset in South Africa using duration analysis. BMJ Open 2016;6: e011076. doi:10.1136/ bmjopen-2016-011076

- Prepublication history for this paper is available online. To view these files please visit the journal online (http://dx.doi.org/10.1136/ bmjopen-2016-011076).

Received 11 January 2016 Revised 24 June 2016 Accepted 28 June 2016
CrossMark

School of Economics, University of Cape Town, Cape Town, Western Cape, South Africa

Correspondence to Dr Nicole Vellios; nicolevellios@gmail.com

\section{ABSTRACT}

Objectives: South Africa has achieved significant success with its tobacco control policy. Between 1994 and 2012, the real price of cigarettes increased by $229 \%$, while regular smoking prevalence decreased from about $31 \%$ to $18.2 \%$.

Methods: Cigarette prices and socioeconomic variables are used to examine the determinants of regular smoking onset. We apply duration analysis techniques to the National Income Dynamics Study, a nationally representative survey of South Africa.

Results: We find that an increase in cigarette prices significantly reduces regular smoking initiation among males, but not among females. Regular smoking among parents is positively correlated with smoking initiation among children. Children with more educated parents are less likely to initiate regular smoking than those with less educated parents. Africans initiate later and at lower rates than other race groups.

Conclusions: As the tobacco epidemic is shifting towards low-income and middle-income countries, there is an increasing urgency to perform studies in these countries to influence policy. Higher cigarette excise taxes, which lead to higher retail prices, reduce smoking prevalence by encouraging smokers to quit and by discouraging young people from starting smoking.

\section{INTRODUCTION}

A substantial body of literature has conclusively shown that there is an inverse relationship between tobacco prices and tobacco consumption. ${ }^{1}$ By increasing the excise tax, governments are typically able to increase the retail price of tobacco products, which induces current smokers to quit, reduces the consumption of continuing smokers and reduces the initiation of tobacco products by potential smokers. This paper considers determinants of regular smoking initiation, and in particular the impact of the price of cigarettes on regular smoking initiation in South Africa.

The International Agency for Research on Cancer (IARC) found that there is sufficient

\section{Strengths and limitations of this study}

- This study uses a nationally representative data set.

- We use duration analysis to investigate the effectiveness of prices in discouraging regular smoking initiation in a low-income and middle-income country, which has relevance for other low-income and middle-income countries considering increasing excise taxes.

- We create a pseudo-panel to track individuals over time.

- Some variables are time invariant (gender, population group), while other variables are time variant (price of cigarettes).

evidence $^{\mathrm{i}}$ to conclude that increases in tobacco taxes that increase prices reduce the initiation and uptake of tobacco use among young people. ${ }^{1}$ Guindon ${ }^{2}$ subsequently conducted an extensive literature review on the impact of tobacco prices on smoking initiation. He identified 27 studies and found that the effect of price on the smoking initiation decision differs across these studies and argues that data, measurement and methodological issues inherent in much of the literature affect the results. ${ }^{2}$ Guindon ${ }^{2}$ concludes that the evidence that taxes or tobacco prices impact smoking initiation is not strong. Two papers, which are not covered in Guindon's review, find that cigarette taxes and prices affect smoking initiation decisions in the USA and in Canada. ${ }^{34}$

The existing literature is dominated by studies performed in high-income countries, while only several studies consider the determinants of smoking initiation in low-income and middle-income countries. Two of these are based on Vietnamese data and found that tobacco prices have a statistically

'Sufficient evidence' is defined as follows: 'An association has been observed between the intervention under consideration and a given effect in studies in which chance, bias and confounding can be ruled out with reasonable confidence. The association is highly likely to be causal' (IARC, 2011: 355). 
significant and fairly substantial effect on smoking initiation. $^{5}{ }^{6}$ The third study looks at six low-middle and eight upper-middle-income countries and finds that higher prices reduce smoking initiation in low-income and middle-income countries and promote cessation in upper-income and middle-income countries. ${ }^{7}$ The fourth study looks at 48 countries of which 40 are developing countries and finds that price increases effectively reduce initiation in early youth. ${ }^{8}$ The fifth study analyses life-course smoking behaviour in China and finds that cigarette prices have a small and insignificant effect on smoking initiation. ${ }^{9}$

It is now possible to fill this gap in our knowledge with respect to smoking initiation in low-income and middle-income countries, thanks to the rapid growth in the number of large household surveys in those countries over the past decade.

We chose data from South Africa since it is at the forefront of middle-income countries in using excise tax increases as a tobacco control measure. A democratically elected government came to power in May 1994 and made primary and preventative healthcare a strategic priority. As part of the focus, the government has consistently increased the excise tax on tobacco products since 1994 and passed fairly stringent tobacco control legislation in 1999. The explicit rationale for raising the excise tax was to reduce tobacco use and advance public health, although a welcome side effect was that it raised excise tax revenues as well. ${ }^{10}$

Between 1994 and 2012, the real excise tax increased by $407 \%$ and the real price of cigarettes increased by $229 \%$ (see figure 1). Over this period, aggregate legal consumption of cigarettes fell by $38 \%$, per capita consumption fell by $52 \%$ and regular smoking prevalence decreased from about $31 \%$ to $18.2 \% .^{10} 11$ The relatively large increases in cigarette prices over nearly 20 years allow one to investigate the relationship between cigarette prices and regular smoking initiation.

\section{DATA}

We use data from the first three waves of the National Income Dynamics Study (NIDS), which is the first nationally representative household panel study in South Africa. ${ }^{12-14}$ A stratified, two-stage cluster sample design was used in sampling the households to be included in the base wave. ${ }^{15}$ Although the data are longitudinal, we did not use the longitudinal characteristics of the data, primarily because the change in the real price between waves was modest (only $4 \%$ per year between 2008 and 2012). Instead, we combined data from all three waves to increase the sample size. The same individuals across waves are entered only once in the study sample.

NIDS has five smoking-related questions, of which three are relevant for this study. The questions 'Do you smoke cigarettes?' and 'Did you ever smoke cigarettes regularly?' were used to identify ever-smokers. Current smokers and former smokers were asked 'How old were you when you first smoked cigarettes regularly?'. Since 'smoking' and 'regular smoking' are not specifically defined in the NIDS questionnaire (eg, every day, at least 3 days a week, at least every week), it is open to different interpretations by respondents, resulting in some measurement error. This information, together with information on the year of birth, was used to determine the year in which the person started regular smoking. The descriptive statistics of the sample (unweighted data) are shown in table 1.

As is typical of panel studies, there were sometimes substantial differences in respondents' answers about their smoking behaviour between waves. A person was coded as an ever-smoker if he or she indicated in at least
Figure 1 Aggregate cigarette consumption and price of cigarettes, 1970-2013.

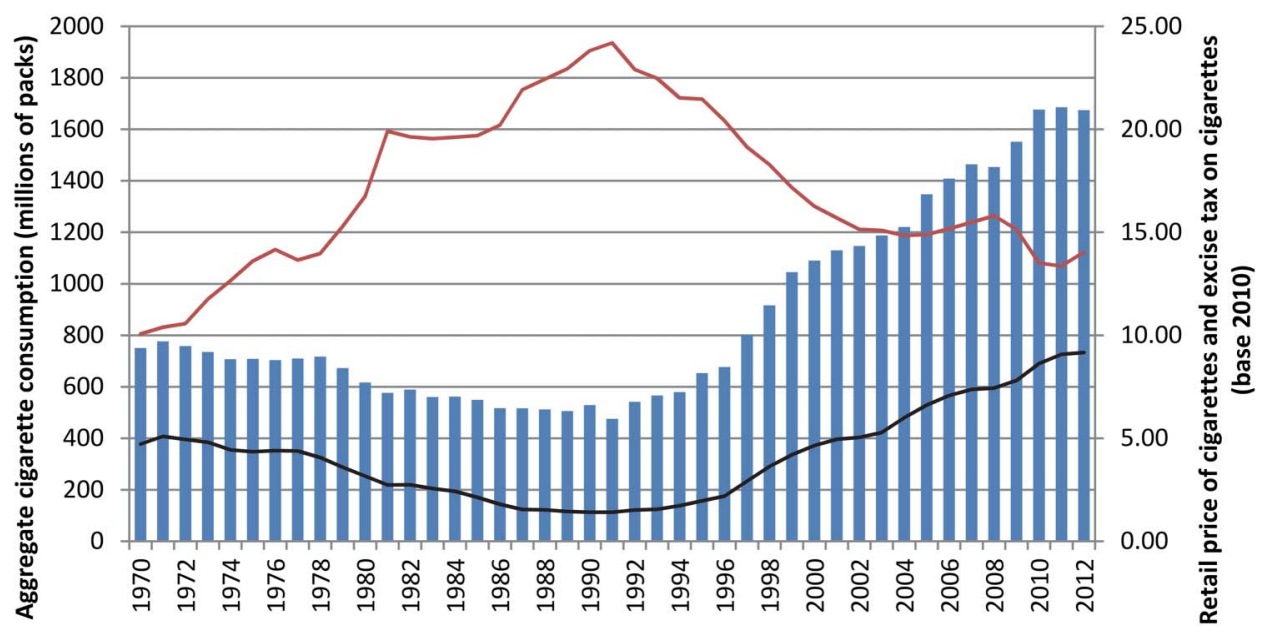

Retail price of cigarettes (base 2010) (secondary axis)

_-Aggregate cigarette consumption (million packs)

—_Excise tax per pack (base 2010) (secondary axis)

Source: Van Walbeek 2005, Statistics South Africa (various issues) 
teenager. Given the well-established relationship between education and income, parents' education is likely to be a better indicator of household income at the time the person was susceptible to starting smoking than current income levels. The variable is coded as either parent's highest level of education. ${ }^{\text {ii }}$

In order to account for the fact that there may be unobserved determinants of smoking behaviour, we considered including unemployment and per capita gross domestic product (GDP) in the regression equation. ${ }^{26}$ However, given measurement errors over time in unemployment and per capita GDP, and the fact that per capita GDP is quite a distorted measure of average income in South Africa, we include a proxy for confidence in the economy, calculated as gross domestic capital formation as a percentage of GDP.

We tested the robustness of the results by means of a discrete-time split population model, which relaxes the assumption that all individuals will eventually start regular smoking. This approach has been followed in a number of other studies. ${ }^{5} 18{ }^{19}$ In the initial analysis, we tested the impact of tobacco control policy changes in 1995 (warning labels on tobacco packaging and advertising material, and ban on smoking on public transport) and 2001 (tobacco advertising and sponsorship ban, prohibition of smoking in all public and workplaces and prohibition of distributing free cigarettes and the sale of single cigarettes), but the impact was found to be insignificant. The models were estimated using Stata V.12.1. Split population models were estimated using the spsurv command. ${ }^{\text {iii }}$

\section{RESULTS}

The results of the determinants of regular smoking initiation for males and females are presented in tables 2 and 3, respectively. Models 1-3 exclude the impact of parental regular smoking. Models 1 and 3 account for duration dependency by including temporal dummies. Model 3 is the spsurv estimation. Models 2, 4 and 5 account for duration dependency using a fourth-order polynomial.

The samples in models 4 and 5 are much smaller since we do not have information on parental regular smoking for all respondents. Since we only have parental regular smoking information at the time of the interview, the variable is time invariant. Model 4 is included as a reference to model 5 so that the effects of parental regular smoking can be analysed in comparison to the same sample of individuals.

The estimated ORs for models 1 and 2 and the HR for model 3 are broadly similar, at least within each gender group. Males' regular smoking initiation is

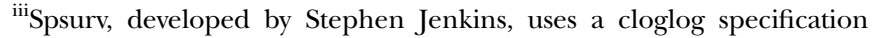
which reports HRs (not ORs). The response curve is asymmetric, unlike the logit specification.
}

significantly affected by the price of cigarettes. These price effects are likely to be upper limits because we do not control for other tobacco control interventions of 1995 and 2001. The OR on the price variable of 0.984 (model 1) implies that a male who is subject to a 1 rand (about US $\$ 0.10$ in 2014) increase in the price has a $1.6 \%((1-0.984) \times 100)$ lower probability of initiating regular smoking than a male who is not subject to the price increase. For model 2, a one rand increase reduces the probability of regular smoking initiation among males by $1.7 \%$. These results are scalable; a 10 rand (about US $\$ 1.00$ ) increase in the price of cigarettes reduces the probability of starting regular smoking by between $14.8 \%\left(=1-\mathrm{e}^{-0.016 \times 10}\right)$ and $15.6 \%\left(=1-\mathrm{e}^{-0.017 \times 10}\right)$. Whereas these results refer to the percentage change in regular smoking initiation in response to an absolute change in the price, the price elasticity of initiation refers to the percentage change in regular smoking initiation in response to a percentage change in the price. This elasticity suggests that for every $10 \%$ increase in price, the probability of initiation among males decreases by $2.1 \%$ at the mean (table 2 , model 1 ). On the other hand, females' regular smoking initiation for the sample as a whole is not significantly impacted by the price of cigarettes.

Living in an urban area increases the probability of initiating regular smoking for males $(\mathrm{OR}=1.232$, 95\% CI 1.127 to 1.345$)$ and females (OR=1.500, 95\% CI 1.244 to 1.809) (model 1).

We tested the robustness of the results using lowprice/discounted brands (which comprise 10-15\% of the market) and found that the estimates were similar to those of the popular price category brands.

In terms of socioeconomic status, there is a negative socioeconomic gradient for regular smoking initiation, but for males only. Compared to the base (where the most educated parent has primary education or less), the probability of initiating regular smoking decreases, although not significantly so, if the most educated parent has completed secondary school $(\mathrm{OR}=0.960,95 \%$ CI 0.820 to 1.123 ), and becomes significantly lower if the most educated parent has some tertiary education $(\mathrm{OR}=0.774,95 \%$ CI 0.638 to 0.939$)$.

A total of $82.4 \%$ of males and $82.0 \%$ of females in the sample indicate that they are literate. Being literate significantly reduces the probability of initiating regular smoking, for both males and females $(\mathrm{OR}=0.615,95 \%$ CI 0.557 to 0.680 for males and $\mathrm{OR}=0.6184,95 \%$ CI 0.511 to 0.739 for females).

Approximately $5.5 \%$ of respondents indicated that their mother died before they were aged 15 years. For males, having lost one's mother before age 15 is positively, but insignificantly, associated with regular smoking initiation (table 2, model 1: OR=1.091, 95\% CI 0.906 to 1.313). For females, having lost one's mother by age 15 is positively and significantly associated with regular smoking initiation (table 3, model 1 : OR=1.353, 95\% CI 0.999 to 1.839 ). 
Table 2 Determinants of regular smoking initiation for males (ORs)

\begin{tabular}{|c|c|c|c|c|c|}
\hline & $\begin{array}{l}\text { (1) } \\
\text { Logit }\end{array}$ & $\begin{array}{l}(2) \\
\text { Logit }\end{array}$ & $\begin{array}{l}\text { (3) } \\
\text { Split } \\
\text { population }\end{array}$ & $\begin{array}{l}\text { (4) } \\
\text { Logit }\end{array}$ & $\begin{array}{l}\text { (5) } \\
\text { Logit }\end{array}$ \\
\hline Price of cigarettes & $\begin{array}{l}0.984^{\star * *} \\
(0.003)\end{array}$ & $\begin{array}{l}0.983^{* * *} \\
(0.004)\end{array}$ & $\begin{array}{l}0.990^{\star * \star} \\
(0.003)\end{array}$ & $\begin{array}{l}0.975^{\star * *} \\
(0.008)\end{array}$ & $\begin{array}{l}0.970^{* * *} \\
(0.008)\end{array}$ \\
\hline Rural & 1.000 & 1.000 & 1.000 & 1.000 & 1.000 \\
\hline Urban & $\begin{array}{l}1.232^{\star \star \star} \\
(0.051)\end{array}$ & $\begin{array}{l}1.267^{\star \star \star} \\
(0.053)\end{array}$ & $\begin{array}{l}1.336^{\star \star \star} \\
(0.052)\end{array}$ & $\begin{array}{l}1.548^{\star \star *} \\
(0.163)\end{array}$ & $\begin{array}{l}1.467^{\star \star \star} \\
(0.156)\end{array}$ \\
\hline Parents: primary/no education & 1.000 & 1.000 & 1.000 & 1.000 & 1.000 \\
\hline Parents: incomplete secondary education & $\begin{array}{l}1.039 \\
(0.050)\end{array}$ & $\begin{array}{l}0.997 \\
(0.047)\end{array}$ & $\begin{array}{l}1.030 \\
(0.063)\end{array}$ & $\begin{array}{l}0.834^{*} \\
(0.085)\end{array}$ & $\begin{array}{l}0.894 \\
(0.091)\end{array}$ \\
\hline Parents: complete secondary education & $\begin{array}{l}0.960 \\
(0.077)\end{array}$ & $\begin{array}{l}0.889 \\
(0.071)\end{array}$ & $\begin{array}{l}0.918 \\
(0.100)\end{array}$ & $\begin{array}{l}0.954 \\
(0.168)\end{array}$ & $\begin{array}{l}1.041 \\
(0.186)\end{array}$ \\
\hline Parents: at least some tertiary education & $\begin{array}{l}0.774^{\star \star \star} \\
(0.076)\end{array}$ & $\begin{array}{l}0.730^{\star \star \star} \\
(0.071)\end{array}$ & $\begin{array}{l}0.743^{\star \star \star} \\
(0.124)\end{array}$ & $\begin{array}{l}0.677^{\star} \\
(0.137)\end{array}$ & $\begin{array}{l}0.757 \\
(0.154)\end{array}$ \\
\hline Illiterate & 1.000 & 1.000 & 1.000 & 1.000 & 1.000 \\
\hline Literate & $\begin{array}{l}0.615^{\star \star \star} \\
(0.031)\end{array}$ & $\begin{array}{l}0.598^{\star \star \star} \\
(0.030)\end{array}$ & $\begin{array}{l}0.571^{\star \star \star} \\
(0.058)\end{array}$ & $\begin{array}{l}0.683^{\star * *} \\
(0.082)\end{array}$ & $\begin{array}{l}0.716^{\star \star \star} \\
(0.087)\end{array}$ \\
\hline Mother alive when respondent was 15 & 1.000 & 1.000 & 1.000 & 1.000 & 1.000 \\
\hline Mother died before respondent was 15 & $\begin{array}{l}1.091 \\
(0.103)\end{array}$ & $\begin{array}{l}1.075 \\
(0.098)\end{array}$ & $\begin{array}{l}1.047 \\
(0.103)\end{array}$ & $\begin{array}{l}1.731 \\
(0.626)\end{array}$ & $\begin{array}{l}1.482 \\
(0.523)\end{array}$ \\
\hline Confidence in the economy & $\begin{array}{l}0.980^{\star \star *} \\
(0.005)\end{array}$ & $\begin{array}{l}0.974^{* * *} \\
(0.005)\end{array}$ & $\begin{array}{l}0.972^{\star \star \star} \\
(0.005)\end{array}$ & $\begin{array}{l}0.990 \\
(0.015)\end{array}$ & $\begin{array}{l}0.992 \\
(0.015)\end{array}$ \\
\hline Neither parent has ever smoked & & & & & 1.000 \\
\hline Either parent was ever a smoker & & & & & $\begin{array}{l}1.943^{* * *} \\
(0.200)\end{array}$ \\
\hline Duration dependency (temporal dummies) & Yes & No & Yes & No & No \\
\hline Duration dependency (fourth-order polynomial) & No & Yes & No & Yes & Yes \\
\hline Controls for race & Yes & Yes & Yes & Yes & Yes \\
\hline Controls for duration dependency and race group interactions & Yes & Yes & No & Yes & Yes \\
\hline Number of individuals & 7771 & 7771 & 7771 & 1732 & 1732 \\
\hline Number of person-period observations & 96298 & 96426 & 96426 & 18262 & 18262 \\
\hline Pseudo $\mathrm{R}^{2}$ & 0.100 & 0.102 & & 0.115 & 0.124 \\
\hline Price elasticity of initiation & $-0.21^{\star \star \star}$ & $-0.23^{\star \star \star}$ & & $-0.41^{\star \star *}$ & $-0.47^{\star \star \star}$ \\
\hline
\end{tabular}

Source: National Income Dynamics Study (NIDS) wave 1 (2008), wave 2 (2010) and wave 3 (2012).

${ }^{*} p<0.1 ;{ }^{* *} p<0.05 ;{ }^{* * *} p<0.01$.

An increase in confidence in the economy is associated with a decrease in the probability of smoking initiation for males (table 2, model 1: OR=0.980, 95\% CI 0.970 to 0.990 ) and females (table 3 , model 1 : $\mathrm{OR}=0.995$, 95\% CI 0.979 to 1.010 ), but this result is only significant for males.

The NIDS questionnaire did not ask respondents about the smoking behaviour of their parents. We thus used a subset of the data where we were able to link the parents' regular smoking-related responses to the children's responses (1732 males and 1986 females, compared to the full sample of 7771 males and 9920 females). For both males and females (model 5 of tables 2 and 3), having at least one parent who smokes is correlated with the probability of initiating regular smoking (OR=1.943, 95\% CI 1.587 to 2.378 for males and $\mathrm{OR}=2.064,95 \%$ CI 1.371 to 3.107 for females).

In each of the estimated models above (except the split population model), we included race and time-at-risk interaction terms in order to determine the regular smoking initiation hazard rates for each of the race groups. Based on models 1 and 2, we derived the probability of initiating regular smoking for Africans, mixed-race ancestry, and whites and Asians (the latter two groups combined). In all cases, we assume a typical person is literate, lives in an urban area, has at least one parent who has completed secondary school and whose mother did not die before the person was aged 15 years. The price of cigarettes is assumed to be at the 2008 level (ie, R21.41 per pack in constant December 2010 prices). The results for males and females are shown in figures 2 and 3 , respectively.

The irregularity of the hazard functions based on the temporal dummy specification (shown as the thin lines of the spiked curves in figures 2 and 3) reflects the heaping effect and recall error. For example, there are substantial spikes at ages 16 and 18 . The smoothed hazard functions based on the fourth-order polynomial specification do not suffer from the heaping effect distortions. Based on the smoothed estimates, regular smoking initiation is 
Table 3 Determinants of regular smoking initiation for females (ORs)

\begin{tabular}{|c|c|c|c|c|c|}
\hline & $\begin{array}{l}\text { (1) } \\
\text { Logit }\end{array}$ & $\begin{array}{l}\text { (2) } \\
\text { Logit }\end{array}$ & $\begin{array}{l}\text { (3) } \\
\text { Split } \\
\text { population }\end{array}$ & $\begin{array}{l}\text { (4) } \\
\text { Logit }\end{array}$ & $\begin{array}{l}(5) \\
\text { Logit }\end{array}$ \\
\hline Price of cigarettes & $\begin{array}{l}0.994 \\
(0.006)\end{array}$ & $\begin{array}{l}0.995 \\
(0.006)\end{array}$ & $\begin{array}{l}1.004 \\
(0.007)\end{array}$ & $\begin{array}{l}0.982 \\
(0.011)\end{array}$ & $\begin{array}{l}0.982 \\
(0.011)\end{array}$ \\
\hline Rural & 1.000 & 1.000 & 1.000 & 1.000 & 1.000 \\
\hline Urban & $\begin{array}{l}1.500^{* * *} \\
(0.143)\end{array}$ & $\begin{array}{l}1.555^{\star * *} \\
(0.144)\end{array}$ & $\begin{array}{l}1.702^{* * *} \\
(0.085)\end{array}$ & $\begin{array}{l}1.604^{* * *} \\
(0.311)\end{array}$ & $\begin{array}{l}1.511^{\star *} \\
(0.290)\end{array}$ \\
\hline Parents: primary/no education & 1.000 & 1.000 & 1.000 & 1.000 & 1.000 \\
\hline Parents: incomplete secondary education & $\begin{array}{l}1.088 \\
(0.093)\end{array}$ & $\begin{array}{l}1.059 \\
(0.087)\end{array}$ & $\begin{array}{l}1.072 \\
(0.076)\end{array}$ & $\begin{array}{l}1.083 \\
(0.163)\end{array}$ & $\begin{array}{l}1.104 \\
(0.167)\end{array}$ \\
\hline Parents: complete secondary education & $\begin{array}{l}1.100 \\
(0.147)\end{array}$ & $\begin{array}{l}1.033 \\
(0.134)\end{array}$ & $\begin{array}{l}1.100 \\
(0.155)\end{array}$ & $\begin{array}{l}1.222 \\
(0.328)\end{array}$ & $\begin{array}{l}1.296 \\
(0.357)\end{array}$ \\
\hline Parents: at least some tertiary education & $\begin{array}{l}1.294^{*} \\
(0.190)\end{array}$ & $\begin{array}{l}1.199 \\
(0.172)\end{array}$ & $\begin{array}{l}1.211 \\
(0.144)\end{array}$ & $\begin{array}{l}1.298 \\
(0.331)\end{array}$ & $\begin{array}{l}1.522 \\
(0.394)\end{array}$ \\
\hline Illiterate & 1.000 & 1.000 & 1.000 & 1.000 & 1.000 \\
\hline Literate & $\begin{array}{l}0.614^{\star \star *} \\
(0.058)\end{array}$ & $\begin{array}{l}0.584^{\star * *} \\
(0.053)\end{array}$ & $\begin{array}{l}0.529^{\star * *} \\
(0.089)\end{array}$ & $\begin{array}{l}0.716^{\star} \\
(0.136)\end{array}$ & $\begin{array}{l}0.750 \\
(0.143)\end{array}$ \\
\hline Mother alive when respondent was 15 & 1.000 & 1.000 & 1.000 & 1.000 & 1.000 \\
\hline Mother died before respondent was 15 & $\begin{array}{l}1.355^{\star \star} \\
(0.211)\end{array}$ & $\begin{array}{l}1.302^{*} \\
(0.195)\end{array}$ & $\begin{array}{l}1.113 \\
(0.160)\end{array}$ & $\begin{array}{l}1.981 \\
(0.856)\end{array}$ & $\begin{array}{l}1.819 \\
(0.788)\end{array}$ \\
\hline Confidence in the economy & $\begin{array}{l}0.995 \\
(0.008)\end{array}$ & $\begin{array}{l}0.988 \\
(0.088)\end{array}$ & $\begin{array}{l}0.984 \\
(0.007)\end{array}$ & $\begin{array}{l}0.972 \\
(0.024)\end{array}$ & $\begin{array}{l}0.974 \\
(0.024)\end{array}$ \\
\hline Neither parent has ever smoked & & & & & 1.000 \\
\hline Either parent was ever a smoker & & & & & $\begin{array}{l}2.064^{\star \star \star} \\
(0.431)\end{array}$ \\
\hline Duration dependency (temporal dummies) & Yes & No & Yes & No & No \\
\hline Duration dependency (fourth-order polynomial) & No & Yes & No & Yes & Yes \\
\hline Controls for race & Yes & Yes & Yes & Yes & Yes \\
\hline Controls for duration dependency and race group interactions & Yes & Yes & No & Yes & Yes \\
\hline Number of individuals & 9920 & 9920 & 9920 & 1986 & 1986 \\
\hline Number of person-period observations & 159818 & 161071 & 161071 & 25546 & 25546 \\
\hline Pseudo $\mathrm{R}^{2}$ & 0.232 & 0.236 & & 0.241 & 0.245 \\
\hline Price elasticity of initiation & -0.08 & -0.07 & & -0.28 & -0.28 \\
\hline
\end{tabular}

Source: National Income Dynamics Study (NIDS) wave 1 (2008), wave 2 (2010) and wave 3 (2012).

${ }^{*} \mathrm{p}<0.1 ;{ }^{* *} \mathrm{p}<0.05 ;{ }^{* \star *} \mathrm{p}<0.01$.

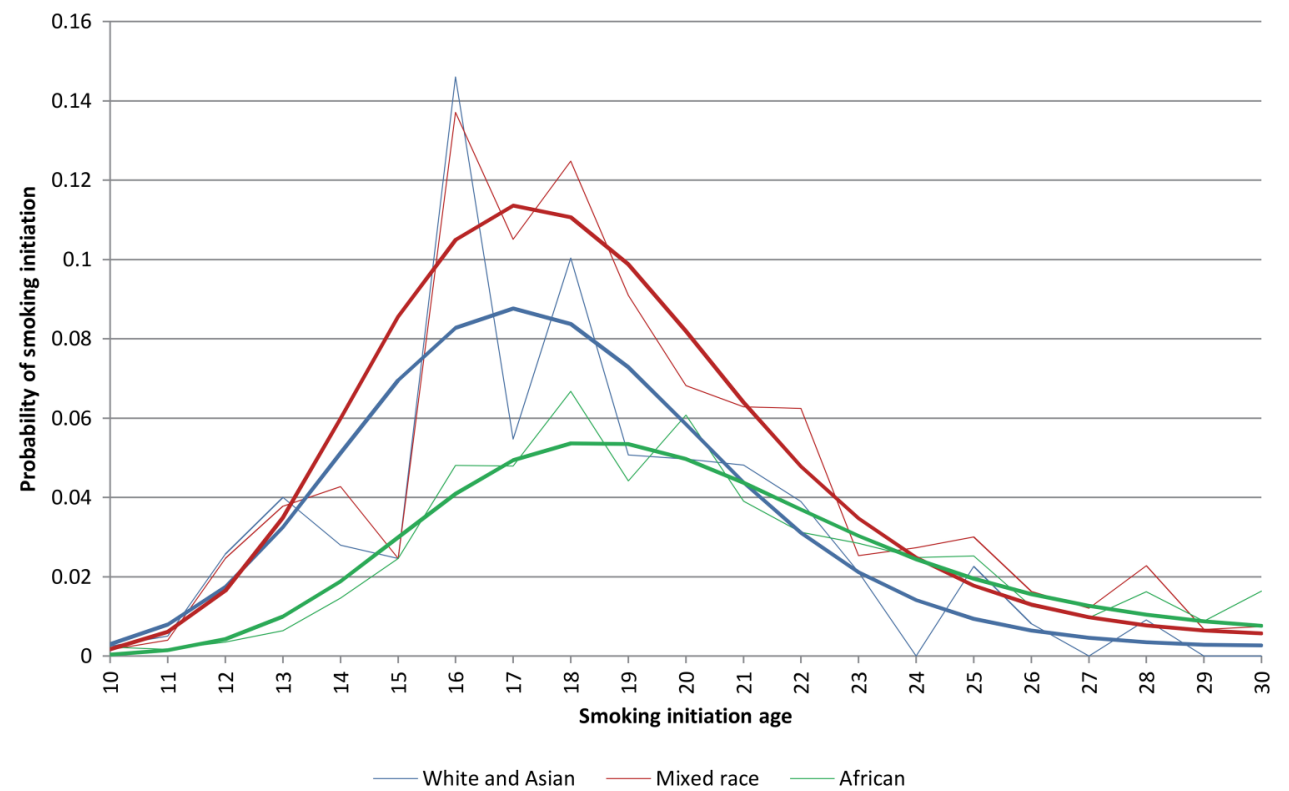

Figure 2 Regular smoking initiation hazard rates for males, by race. 


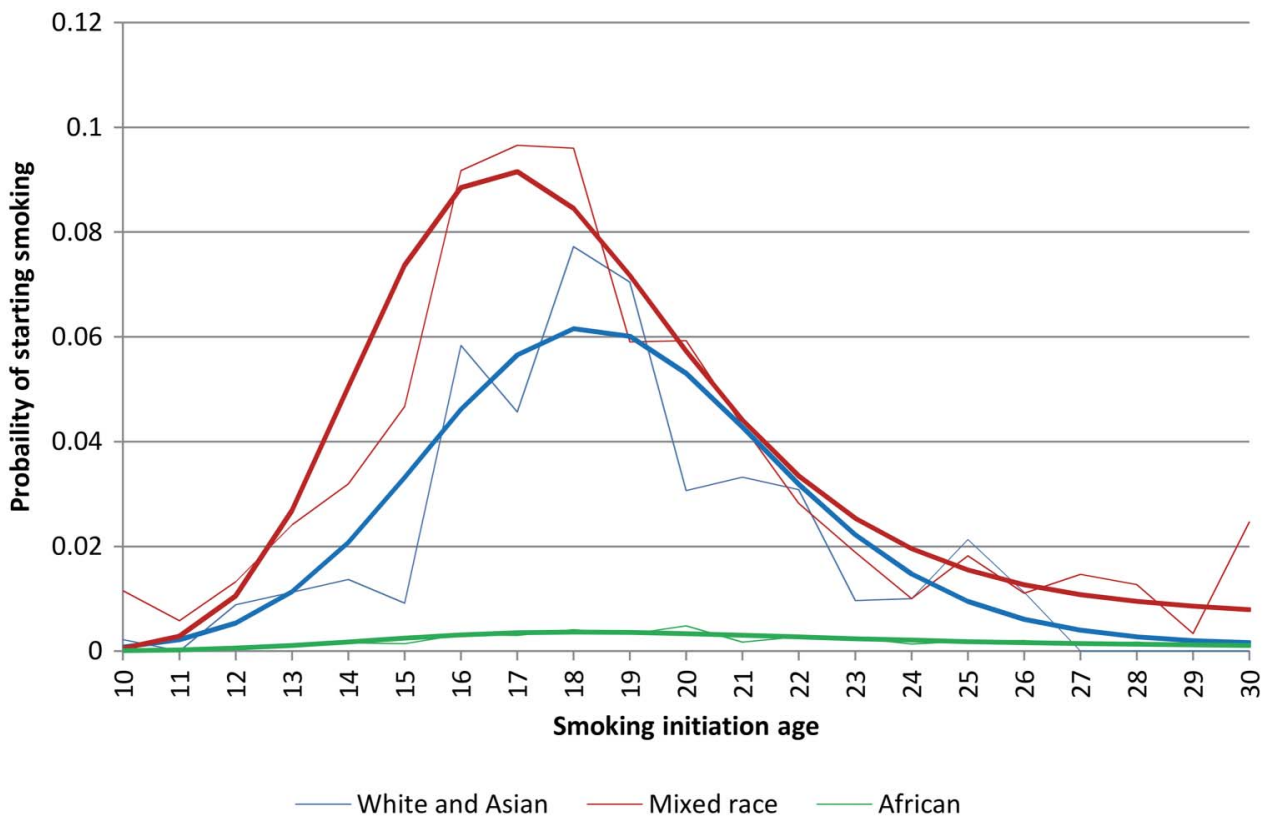

Figure 3 Regular smoking initiation hazard rates for females, by race.

highest among mixed-race males, peaking at age 17.2 years with a hazard rate of $0.114 .^{\text {iv }}$ Thus, $\sim 11.4 \%$ of mixed-race males who have not initiated regular smoking and who have the characteristics described in the previous paragraph are expected to initiate regular smoking past their 17th birthday. Among whites and Asians, the regular smoking initiation hazard peaks at 17.0 years, at a hazard rate of 0.088 . Regular smoking initiation is substantially lower among Africans and peaks substantially later (18.5 years), at a hazard rate of 0.054 .

Female regular smoking initiation in South Africa is lower than male regular smoking initiation. There are large differences in female regular smoking initiation between race groups. Among mixed-race females, regular smoking initiation peaks at 16.8 years, with a hazard rate of 0.092. Regular smoking initiation among white and Asian females peaks at 18.3 years, with a hazard rate of 0.062 . Very few African females initiate regular smoking, indicated by the fact that the hazard peaks at 18.1 years at 0.002 .

\section{DISCUSSION}

The current study contributes to the growing literature on regular smoking onset in low-income and middle-income countries. Since the tobacco epidemic is shifting towards low-income and middle-income countries, there is an increasing urgency to perform studies in these countries. Higher cigarette excise taxes, which lead to higher retail prices, reduce regular smoking prevalence by encouraging smokers to quit and by discouraging young people from starting regular smoking.

\footnotetext{
${ }^{\mathrm{iv}}$ The decimals were derived using a more precise gradation of length of time at risk than the integer values shown in table 2 .
}

We found that the increase in cigarette prices from R7.24 in 1994 to R20.93 in 2012 decreased regular smoking initiation among males by between $14.0 \%$ and $20.8 \%$, depending on the specification of the model.

For the full female sample, we do not find a significant relationship between the price of cigarettes and regular smoking initiation, a result in line with others. ${ }^{1718}{ }^{27}$ For a subsample of females for which we have information on parental regular smoking behaviour, an increase in cigarette prices reduces regular smoking initiation, although the effect is only significant at the $10 \%$ level.

We estimate the price elasticity of initiation is between -0.21 and -0.47 for males and -0.07 to -0.28 for females, depending on the specification. The price elasticity is significant for males only, a similar finding to Cawley et $a l^{27}$ In general, our price elasticities of initiation are lower compared to other studies. Cawley $e t a l^{27}$ find a price elasticity of initiation of -1.2 for males. Laxminarayan and Deolalikar ${ }^{6}$ consider smoking initiation among Vietnamese males and find a price elasticity of initiation of -1.18 . Zhang $e t a l^{28}$ find an elasticity of initiation with respect to cigarette price is -3.36 for males and females in Canada. ${ }^{6}$

While an increase in the price of cigarettes has a direct impact on regular smoking initiation among males, it also has an indirect impact on both males and females. The results indicate that regular smoking initiation is correlated with regular parental smoking. Regular smoking prevalence in South Africa has decreased sharply over the past 20 years, primarily because of an increase in the price of cigarettes. ${ }^{10}$

Furthermore, we find a negative gradient between parents' education and regular smoking initiation. Children of parents with limited education are more 
likely to start regular smoking than children of parents with more education. Education levels in South Africa are gradually improving over time, and should the trends found in this paper continue, this should gradually lead to reduced regular smoking initiation in the next generation. Closely associated with this is the finding that literate people are less likely to initiate regular smoking than illiterate people. As education levels improve, illiteracy recedes, with positive long-term tobacco control consequences.

While the relationship between parents' education and smoking behaviour on young people's regular smoking initiation (especially males) has positive tobacco control consequences in the long term, these operate too slowly to have practical application as a tobacco control mechanism. A more urgent approach is required. In this context, it is encouraging to see that the large increases in the price of cigarettes in South Africa over the past two decades have resulted in higher quit rates and have significantly decreased regular smoking initiation among males, who comprise by far the largest group of smokers (and potential smokers) in South Africa.

We note several limitations. First, there is likely to be recall error since individuals often do not remember the exact age they started regular smoking. We attempted to reduce the impact of recall error by limiting the sample to all individuals who were younger than 48 years in 2008 and accounting for heaping by interacting price with the years where heaping is most visible (ages 16 and 18). Second, we do not account for price variation across brands. Before 2000, this would not have impacted the results significantly since there was little variation in prices across brands. However, since 2000, there has been an increase in price variation across brands. For the years 2002-2005 and 2007-2012, we match cigarette prices by province to current province where the respondent resides at the time of interview. Since province at the time of interview and province at the time of making the decision to start smoking may not be the same, there is likely to be some measurement error. Third, we do not account for an HIV-related mortality bias. In a country where the prevalence of the AIDS epidemic is high, it is possible that a mortality bias might affect the sample if the propensity of HIV infection is correlated with smoking through risk preferences. If the distribution of risk preferences has changed over time, then this will affect the price elasticity of the price estimates. Fourth, it is possible that the effect of parental smoking may be attenuated by a gene-grounded propensity to act impulsively. Fifth, the price coefficients may be biased if prices are endogenous. Producers may set their prices as a function of consumer tastes and consumers' expected price responses.

South Africa should continue to increase the price of cigarettes through excise taxes. However, if consumers are able to buy cheaper illicit cigarettes, the impact of price increases is likely to be reduced. Governments should therefore implement measures to reduce the illicit trade of cigarettes as outlined by the WHO's Framework Convention on Tobacco Control's Protocol to Reduce Illicit Trade. ${ }^{29}$

Acknowledgements The authors are very grateful to Emmanuel Guindon from the Centre for Health Economics and Policy Analysis at McMaster University for his assistance with the methodology.

Contributors CVW conceived of the study. NV conducted the literature review. CvW and NV contributed to data analysis and writing of the paper.

Funding This work was supported by the Bill \& Melinda Gates Foundation through the American Cancer Society (IRMA 17078) and the African Capacity Building Foundation (IRMA 20177).

Competing interests None declared.

Provenance and peer review Not commissioned; externally peer reviewed.

Data sharing statement No additional data are available.

Open Access This is an Open Access article distributed in accordance with the Creative Commons Attribution Non Commercial (CC BY-NC 4.0) license, which permits others to distribute, remix, adapt, build upon this work noncommercially, and license their derivative works on different terms, provided the original work is properly cited and the use is non-commercial. See: http:// creativecommons.org/licenses/by-nc/4.0/

\section{REFERENCES}

1. International Agency for Research on Cancer. IARC Handbooks of Cancer Prevention, tobacco control, volume 14: Effectiveness of Tobacco Tax and Price: Policies for Tobacco Control. Lyon, France, 2011.

2. Guindon GE. The impact of tobacco prices on smoking onset: a methodological review. Tob Control 2014;23:e5.

3. Lillard DR, Molloy E, Sfekas A. Smoking initiation and the iron law of demand. $J$ Health Econ 2013;32:114-27.

4. Auld MC, Zarrabi M. Long-term effects of tobacco prices faced by adolescents. Forum Health Econ Policy 2015;18:1-24.

5. Guindon GE. The impact of tobacco prices on smoking onset in Vietnam: duration analysis of retrospective data. Euro $J$ Health Econ 2014;15:19-39.

6. Laxminarayan R, Deolalikar A. Tobacco initiation, cessation, and change: evidence from Vietnam. Health Econ 2004;13:1191-201.

7. Kostova D, Chaloupka FJ, Shang C. A duration analysis of the role of cigarette prices on smoking initiation and cessation in developing countries. Eur J Health Econ 2015;16:279-88.

8. Kostova D. A (nearly) global look at the dynamics of youth smoking initiation and cessation: the role of cigarette prices. Appl Econ 2013;45:3943-51.

9. Kenkel D, Lillard DR, Liu F. An analysis of life-course smoking behaviour in China. Health Econ 2009;18:147-56.

10. Van Walbeek CP. "The Economics of Tobacco Contol in South Africa". PhD diss., University of Cape Town, 2005.

11. Shisana O, Labadarios D, Rehle T, et al. South African National Health and Nutrition Examination Survey (SANHANES-1). Cape Town: HSRC Press, 2013.

12. Southern Africa Labour and Development Research Unit. National Income Dynamics Study 2008, Wave 1 [dataset]. Version 5. Cape Town: Southern Africa Labour and Development Research Unit [producer], 2009. Cape Town: DataFirst [distributor] 2014.

13. Southern Africa Labour and Development Research Unit. National Income Dynamics Study 2010-2011, Wave 2 [dataset]. Version 2. Cape Town: Southern Africa Labour and Development Research Unit [producer], 2014. Cape Town: DataFirst [distributor] 2014.

14. Southern Africa Labour and Development Research Unit. National Income Dynamics Study 2012, Wave 3 [dataset]. Version 1. Cape Town: Southern Africa Labour and Development Research Unit [producer], 2014. Cape Town: DataFirst [distributor] 2014.

15. Leibbrandt M, Woolard I, De Villiers L. National Income Dynamic Study. Methodology: Report on NIDS Wave 1. Technical Paper no. 1. 2009.

16. Singer J, Willett J. Applied longitudinal data analysis: modeling change and event occurrence. New York: Oxford University Press, 2003.

17. Cawley J, Markowitz S, Tauras J. Lighting up and slimming down: the effects if body weight and cigarette prices on adolescent smoking initiation. J Health Econ 2004;23:293-311. 
18. Forster $\mathrm{M}$, Jones $\mathrm{A}$. The role of tobacco taxes in starting and quitting smoking: duration analysis of British data. J R Stat Soc Ser A 2001;164:517-47.

19. Kidd $\mathrm{M}$, Hopkins $\mathrm{S}$. The hazards of starting and quitting smoking: some Australian evidence. Econ Rec 2004;80:177-98.

20. López Nicolás A. How important are tobacco prices in the propensity to start and quit smoking? An analysis of smoking histories from the Spanish National Health Survey. Health Econ 2002;11:521-35.

21. Christopoulou R, Han J, Jaber A, et al. Dying for a smoke: how much does differential mortality of smokers affect estimated life-course smoking prevalence? Prev Med 2011;52:66-70.

22. Lillard DR, Christopoulou R, Gil Lacruz A. Re: "Validation of a method for reconstructing historical rates of smoking prevalence". Am J Epidemiol 2014;180:656-8.

23. Marti J. The impact of tobacco control expenditures on smoking initiation and cessation. Health Econ 2014;23:1397-410.
24. Madden D. Tobacco taxes and starting and quitting smoking: does the effect differ by education? Appl Econ 2007;39:613-27.

25. Etilé $F$, Jones $A$. Schooling and smoking among the baby boomersan evaluation of the impact of educational expansion in France. $J$ Health Econ 2011;30:811-31.

26. Christopoulou R, Lillard DR, Balmori de la Miyar JR. Smoking behavior of Mexicans: patterns by birth-cohort, gender, and education. Int J Public Health 2013;58:335-43.

27. Cawley J, Markowitz A, Tauras J. Obesity, cigarette prices, youth access laws and adolescent smoking initiation. East Econ $J$ 2006;32:149-70.

28. Zhang B, Cohen J, Ferrence R, et al. The impact of tobacco tax cuts on smoking initiation among Canadian young adults. Am J Prev Med 2006;30:474-9.

29. World Health Organization. Framework convention on tobacco control. Protocol to eliminate illicit trade in tobacco products. Geneva, Switzerland, 2013 
Correction: Determinants of regular smoking onset in South Africa using duration analysis

Vellios N, van Walbeek C. Determinants of regular smoking onset in South Africa using duration analysis. BMJ Open 2016;6:e011076. The corresponding author of this paper is 'Nicole Vellios' (not 'Dr Nicole Vellios').

Open Access This is an Open Access article distributed in accordance with the Creative Commons Attribution Non Commercial (CC BY-NC 4.0) license, which permits others to distribute, remix, adapt, build upon this work noncommercially, and license their derivative works on different terms, provided the original work is properly cited and the use is non-commercial. See: http://creativecommons.org/licenses/by-nc/4.0/

BMJ Open 2016;6:e011076corr1. doi:10.1136/bmjopen-2016-011076corr1 